\title{
40. BATHYMETRY OF THE EMPEROR SEAMOUNTS
}

\author{
David A. Calgue, ${ }^{1}$ G. Brent Dalrymple, ${ }^{2}$ H. Gary Greene, ${ }^{2}$ Donna Wald, ${ }^{1}$ Masaru Kono, ${ }^{3}$ and Loren W. Kroenke ${ }^{4}$
}

\section{INTRODUCTION}

The publication, in 1970, of a complete set of detailed bathymetric charts for the North Pacific Ocean (Chase et al., 1970) was a milestone for geologic investigations in the world's largest ocean basin. For the first time, investigators had a reasonably accurate, unified bathymetric base upon which to design experiments, test hypotheses, and compile scientific results. These charts, and their companion Bathymetric Atlas of the North Pacific Ocean (1973), have proved invaluable to our studies, over the last decade, of the Hawaiian-Emperor volcanic chain.

The density and quality of data available to Chase and his colleagues varied widely; the western North Pacific was an area of minimal coverage. Since the charts of Chase et al. (1970) were first published, enough new bathymetric data have been collected in the area of the Emperor seamounts to warrant revision of the bathymetry (Plate 1, in pocket) of this unique volcanic feature.

\section{METHODS AND NEW DATA}

We obtained the bathymetric compilation sheets $(1906 \mathrm{~N}-1910 \mathrm{~N}$ and $2006 \mathrm{~N}-2010 \mathrm{~N})$ used for the charts of Chase et al. (1970) and for the Bathymetric Atlas of the North Pacific Ocean (1973) from the Geologic Data Center, Scripps Institution of Oceanography, La Jolla, California. These compilation sheets are at a scale of 4 inches per degree longitude, and contain the data used by Chase and his colleagues. To this data base we added bathymetric data from the nine cruises listed in Table 1. Tracks for these cruises are shown as an inset on Plate 1.

Contouring in Plate 1 is in meters, assuming a sonic velocity in sea water of $1500 \mathrm{~m} / \mathrm{s}$, with a contour inter$\mathrm{val}$ of 500 meters and a scale of 4 inches per degree longitude. In several places where the newer tracklines (Table 1) crossed older (generally pre-1970) tracklines, the reported depths did not agree, and we adjusted the positions of the older data to fit the newer data. If the older trackline had to be shifted by more than 15 nautical miles, it was discarded.

Two recent cruises provided detailed surveys for several of the seamounts. The recontouring of the

\footnotetext{
${ }^{1}$ Middlebury College, Middlebury, Vermont.

${ }^{2}$ U. S. Geological Survey, Menlo Park, California.

${ }^{3}$ Geophysical Institute, University of Tokyo, Tokyo.

${ }^{4}$ Hawaii Institute of Geophysics, University of Hawaii, Honolulu, Hawaii.
}

southern Emperor seamounts, between Kōkō and Kam$\mathrm{mu}$, is based mainly on the Scripps Institution of Oceanography Cruise Aries Leg VII. The recontouring of Suiko Seamount is based primarily on data obtained in 1968 by the Ocean Research Institute of the University of Tokyo during Cruise KH-68-3 of the Hakuho Maru. This latter survey was supplemented and adjusted, as necessary, using data collected by the U.S.C.G.S. Glacier, the R/V S. P. Lee, and the D/V Glomar Challenger (Leg 55). No new data were available for the area north of Tenji Seamount, and the contours are based solely on the data from the Scripps compilation sheets, converted to a sonic velocity of $1500 \mathrm{~m} / \mathrm{s}$.

Most of the new data were obtained on cruises whose primary objective was to survey the seamounts. These tracklines seldom extend beyond the base of the seamounts themselves. For this reason, we have recontoured only the seamount chain proper, and have not extended the contours across the troughs that flank the Emperor chain.

Although the new information nearly doubles the bathymetric data base for the Emperor seamounts, the new chart is not substantially different from the Chase (1970) chart. The main differences between the two are in the sizes and shapes of several seamounts, particularly Suiko and Nintoku, and in relatively small changes in the positions of several seamounts.

Individual seamounts in the Emperor chain range in morphology from true guyots and tablemounts to sharply pointed peaks, although all the larger ones have relatively flat or gently sloping tops. Depths to seamount tops tend to increase northward along the chain. In size and morphology, the seamounts resemble those in the eastern part of the Hawaiian Ridge, including the island of Hawaii, suggesting that the larger Emperor seamounts are formed by several coalescing shield volcanoes. Table 2 is a summary of the depths and morphological characteristics of the principal seamounts in the Emperor chain.

\section{NAMING OF FEATURES}

The literature of the Emperor seamounts essentially began with the classic paper of Dietz (1954) on Japanese Bathymetric Chart 6901, in which he described twelve of the seamounts and named nine. During the last two and a half decades, several discrepancies in the names of certain features in the Emperor Seamount chain have appeared in the literature. These resulted primarily from the misspellings, from the use of different systems of transliteration, from the appearance, disappearance, 
TABLE 1

Sources of New Data for Bathymetric Chart of the Emperor Seamounts

\begin{tabular}{|c|c|c|c|c|}
\hline $\begin{array}{c}\text { Cruise } \\
\text { Designation }\end{array}$ & Institution & Ship & Cruise Dates & References \\
\hline KH-68-3 & $\begin{array}{l}\text { Ocean Research Institute, } \\
\text { Univ. of Tokyo }\end{array}$ & Hakuhō Maru & 18 July-16 Aug. 1968 & $\begin{array}{l}\text { Tomoda }(1968,1974) \\
\text { Segawa }(1970)\end{array}$ \\
\hline Aries Leg VII & Scripps Institution of Oceanography & $\begin{array}{l}\mathrm{R} / \mathrm{V} \text { Thomas } \\
\text { Washington }\end{array}$ & 27 July-30 Aug. 1971 & Davies et al. $(1971,1972)$ \\
\hline- & $\begin{array}{l}\text { U.S. Coast Guard and } \\
\text { U.S. Geological Survey }\end{array}$ & USCGC Glacier & Sept. 1971 & Bargar et al. (1975) \\
\hline Leg 32 & $\begin{array}{l}\text { Deep Sea Drilling Project, } \\
\text { Scripps Institution of Oceanography }\end{array}$ & $\begin{array}{l}\text { D/V Glomar } \\
\text { Challenger }\end{array}$ & 16 Aug. -10 Oct. 1973 & $\begin{array}{l}\text { Larson, Moberly, et al. } \\
\text { (1975) }\end{array}$ \\
\hline- & $\begin{array}{l}\text { Hawaii Institute of Geophysics, } \\
\text { Univ. of Hawaii }\end{array}$ & R/V Kana Keoki & 19-26 Aug. 1976 & - \\
\hline- & $\begin{array}{l}\text { Hawaii Institute of Geophysics, } \\
\text { Univ. of Hawaii }\end{array}$ & R/V Kana Keoki & 13-24 Sept. 1976 & - \\
\hline Lee 8-76-NP & U.S. Geological Survey & R/V Samuel P. Lee & 29 Sept.-21 Oct. 1976 & $\begin{array}{l}\text { Dalrymple et al. (this } \\
\text { volume) }\end{array}$ \\
\hline- & $\begin{array}{l}\text { Hawaii Institute of Geophysics, } \\
\text { Univ. of Hawaii }\end{array}$ & R/V Kana Keoki & 24 June-4 July 1977 & - \\
\hline Leg 55 & $\begin{array}{l}\text { Deep Sea Drilling Project, } \\
\text { Scripps Institution of Oceanography }\end{array}$ & $\begin{array}{l}\text { D/V Glomar } \\
\text { Challenger }\end{array}$ & 23 July-6 Sept. 1977 & Greene (this volume) \\
\hline
\end{tabular}

TABLE 2

Morphologic Characteristics of Emperor Seamounts

\begin{tabular}{|c|c|c|c|c|c|c|c|c|c|}
\hline Seamount & $\begin{array}{l}\text { Latitude } \\
\text { (N) }\end{array}$ & $\begin{array}{l}\text { Longitude } \\
\text { (E) }\end{array}$ & $\begin{array}{l}\text { Summit } \\
\text { Width } \\
(\mathrm{km})\end{array}$ & $\begin{array}{l}\text { Summit } \\
\text { Length } \\
(\mathrm{km})\end{array}$ & $\begin{array}{c}\text { Summit } \\
\text { Area } \\
\left(\mathrm{km}^{2}\right)\end{array}$ & $\begin{array}{l}\text { Central } \\
\text { Crest } \\
\text { Depth } \\
(\mathrm{m})\end{array}$ & $\begin{array}{l}\text { Elevation } \\
\text { Above Sea } \\
\text { Floor } \\
\text { (m) }\end{array}$ & Morphology & Remarks \\
\hline Meiji & $53^{\circ}$ & $164^{\circ} 30^{\prime}$ & 85 & 170 & 8400 & 2851 & 2100 & Guyot & $\begin{array}{l}\text { Elongated northwest- } \\
\text { southeast }\end{array}$ \\
\hline Detroit & $51^{\circ}$ & $167^{\circ} 30^{\prime}$ & 70 & 130 & 7000 & 2183 & 2800 & Tablemount & $\begin{array}{l}\text { Slightly elongated } \\
\text { north-south }\end{array}$ \\
\hline Tenji & $48^{\circ} 50^{\prime}$ & $168^{\circ} 20^{\prime}$ & 15 & 45 & 900 & 1902 & 4100 & Guyot & Elongated east-west \\
\hline Jimmu & $46^{\circ} 05^{\prime}$ & $169^{\circ} 30^{\prime}$ & 30 & 55 & 825 & 1251 & 4800 & Guyot & Elongated north-south \\
\hline $\begin{array}{l}\text { Seamount } \\
\text { A } \\
\text { (N. Suiko) }\end{array}$ & $45^{\circ} 30^{\prime}$ & $170^{\circ}$ & 15 & 65 & 1135 & 1325 & 4700 & Guyot & Elongated north-south \\
\hline Suiko & $44^{\circ} 35^{\prime}$ & $170^{\circ} 20^{\prime}$ & 40 & 100 & 3250 & 951 & 4500 & $\begin{array}{l}\text { Guyot, gentle } \\
\text { domed }\end{array}$ & $\begin{array}{l}\text { Slightly elongated north- } \\
\text { south direction }\end{array}$ \\
\hline $\begin{array}{l}\text { Seamount } \\
\text { B }\end{array}$ & $43^{\circ}$ & $170^{\circ} 25^{\prime}$ & 20 & 35 & 480 & 1445 & 4000 & Guyot, domed & Nearly circular \\
\hline Yōmei & $42^{\circ} 20^{\prime}$ & $170^{\circ} 25^{\prime}$ & 30 & 55 & 2000 & 915 & 4500 & $\begin{array}{l}\text { Modified pointed- } \\
\text { peaks seamount }\end{array}$ & $\begin{array}{l}\text { Two volcanic peaks } \\
\text { centrally located and } \\
\text { surrounded by a flat } \\
\text { depositional platform }\end{array}$ \\
\hline Nintoku & $41^{\circ}$ & $170^{\circ} 35^{\prime}$ & 25 & 130 & 3400 & 1003 & 5000 & Guyot & Elongated north-south \\
\hline Jingū & $38^{\circ} 47^{\prime}$ & $171^{\circ} 07^{\prime}$ & 10 & 45 & 1300 & 810 & 5200 & Guyot & Elongated north-south \\
\hline $\bar{O}_{j i n}$ & $38^{\circ}$ & $170^{\circ} 40^{\prime}$ & 20 & 65 & 2000 & 899 & 4500 & Guyot & $\begin{array}{l}\text { Downbowed center, } \\
\text { Elongated east-west }\end{array}$ \\
\hline Kōkō & $35^{\circ} 25^{\prime}$ & $171^{\circ} 30^{\prime}$ & 55 & 130 & 5800 & 261 & 4700 & Guyot & $\begin{array}{l}\text { Elongated northwest- } \\
\text { southeast }\end{array}$ \\
\hline Kimmei & $33^{\circ} 42^{\prime}$ & $171^{\circ} 30^{\prime}$ & 15 & 50 & 750 & $\begin{array}{r}409 \\
1601\end{array}$ & $\begin{array}{l}4600 \\
3400\end{array}$ & Guyot-seamount & $\begin{array}{l}\text { One peaked and one flat } \\
\text { top, elongated east-west }\end{array}$ \\
\hline Yūryaku & $32^{\circ} 40^{\prime}$ & $172^{\circ} 15^{\prime}$ & 20 & 35 & 400 & 479 & 4500 & Seamount & Circular-sharp peak \\
\hline Kammu & $32^{\circ} 10^{\prime}$ & $173^{\circ}$ & 20 & 55 & 750 & $\begin{array}{l}338 \\
375\end{array}$ & $\begin{array}{l}4700 \\
4600\end{array}$ & Guyot & $\begin{array}{l}\text { Two flat crestal areas, } \\
\text { elongated northwest- } \\
\text { southeast }\end{array}$ \\
\hline Daikakuji & $32^{\circ} 05^{\prime}$ & $172^{\circ} 17^{\prime}$ & 25 & 40 & 500 & 998 & 4000 & Seamount & $\begin{array}{l}\text { Peaked seamount, nearly } \\
\text { circular }\end{array}$ \\
\hline
\end{tabular}

and relocation of seamounts as new bathymetry became available, and from the use of new names, not formally approved, in the literature.

We have taken this opportunity to rectify these discrepancies and to present a consistent set of formally approved names for the Emperor seamounts. In doing so, we have worked closely with the Advisory Committee on Undersea Features (ACUF) of the United States Board on Geographic Names (USBGN). An explanation of the names used on the new bathymetric chart of the Emperor seamounts is given below. We are indebted to Mr. W. R. Garren, Staff for the ACUF, and to Dr. J. I. 
Tracey, a member of the ACUF, for making much of the following information available to us. The central coordinates for each feature, given in parentheses after the names, are those approved by the USBGN. They are not necessarily at the exact peak or center of the feature, but in all cases are close enough to provide positive association of the name with the feature. The spelling of Japanese names in English is according to the Modified Hepburn Transcription System, used by the USBGN since 1930.

In the descriptions that follow, the Bathymetric Atlas of the North Pacific Ocean (1973) is referred to simply as the Atlas. References to Chart 6901 are to the version published and described by Dietz (1954), unless stated otherwise.

\section{Emperor Seamounts $\left(42^{\circ} 00^{\prime} \mathrm{N}, \mathrm{170}^{\circ} 00^{\prime} \mathrm{E}\right)$}

The name was first applied by Dietz (1954) to the linear range of seamounts that "extends from the vicinity of the intersection of the Aleutian Trench with the Kamchatka Trench to the vicinity of $30^{\circ} \mathrm{N}$. and $174^{\circ} \mathrm{E}$., a distance of about 1500 miles." Dietz named nine of the seamounts for ancient Japanese sovereigns, and most subsequent workers have followed this precedent. Under current usage, the name applies to all the seamounts in the chain, from Meiji Guyot on the north to Kammu Seamount on the south. The name Emperor Seamount Chain was approved by the USBGN in 1963, and amended to Emperor Seamounts in 1971.

Although Dietz (1954) is usually credited with the first description of the Emperor seamounts, they were described by Professor Risaburo Tayama of Tohoku University (Sendai) in 1952. Prof. Tayama, who was also a Division Chief at the Hydrographic Office of the Japanese Maritime Safety Agency, wrote a paper describing the various submarine features revealed on Japanese Chart 6901 in the semi-scientific and semiinformal journal of the Hydrographic Office, Suiro Yoho, or Hydrographic Magazine (Tayama, 1952). Tayama described the seamount chain briefly as follows:

4. Northwest Pacific Ocean

A big submarine ridge (tentatively called the Northwest Pacific Ridge) runs south from the Komandorski Islands, and a chain of seamounts lies on its southern extension to about $25 \mathrm{~N}$ latitude. This submarine ridge-seamount chain and a succession of ridges between the Izu Islands and Tokobay Island bound the area of the Northwest Pacific in the narrow sense. In the Northwest Pacific, the features of the sea floor are quite different from those in the Phillipine Sea. The depth of the sea is 5000-6000 m, which is slightly deeper than the Phillipine Sea.

From the figure that accompanies Tayama's description, it is clear that he was describing what is now the Emperor Seamounts, and that he intended the name Northwest Pacific Ridge to apply to the entire feature.

Dietz studied Chart 6901 while he was in Japan in 1953 as a Fulbright Research Scholar. Tayama's paper was published in Japanese, so Dietz may not have known of its existence when he was preparing his 1954 publication. Dietz presented the results of his study at a seminar in the Geological Institute, University of Tokyo, in October 1953, with a simultaneous transla- tion into Japanese by N. Nasu, now a Professor at the Ocean Research Institute, University of Tokyo. At the seminar, Japanese geologists who were familiar with Tayama's earlier publication asked several questions about the naming of the Emperor seamounts (T. Sato, Hydrographic Office, Maritime Safety Agency, personal communication, 1978). Thus it seems clear that Dietz knew about Tayama's paper and his naming of the seamount chain at least as early as October of 1953. Dietz' paper naming the Emperor seamounts appeared in December of 1954 without reference to Tayama's earlier publication or his earlier naming of the feature.

\section{Daikakuji Seamount $\left(32^{\circ} 05^{\prime} \mathrm{N}, 172^{\circ} 18^{\prime} \mathrm{E}\right)$}

The name was first used informally by Clague (1974) and Dalrymple and Clague (1976), but was misspelled (as Diakakuji). The feature does not appear on Chart 6901. The name was approved by the USBGN in 1979. Daikakuji is the family name of a line of sovereigns (the Southern Court) descending from Kameyama, who acceded to the throne in 1259 and ruled until 1274 as the 90th Emperor.

\section{Detroit Tablemount $\left(51^{\circ} 15^{\prime} \mathrm{N}, 167^{\circ} 45^{\prime} \mathrm{E}\right)$}

This seamount was named for the U.S.S. Detroit, a U.S. Navy light cruiser (CL-8). The first use of this name is uncertain, but it appeared on Chart BC2010N, published by the U.S. Hydrographic Office in 1952. The tablemount is shown, unnamed, on Chart 6901. The name was approved by the USBGN in 1964.

\section{Jingū Seamount $\left(38^{\circ} 50^{\prime} \mathrm{N}, 171^{\circ} 15^{\prime} \mathrm{E}\right)$}

Jing $\bar{u}$ was one of the nine seamounts named by Dietz (1954). The name was approved by the USBGN in 1964. Jingū was the Empress of Emperor Chūi, the 14th Emperor. She reigned from 201 to 269 after the Emperor's death in battle.

\section{Jimmu Seamount $\left(46^{\circ} 00^{\prime} \mathrm{N}, 169^{\circ} 25^{\prime} \mathrm{E}\right)$}

Jimmu was named by Dietz (1954) and the name approved by the USBGN in 1967. Jimmu, who came to the throne about 660 B.C., was the legendary first Emperor of Japan and ruled until about 585 B.C.

In 1969, the USBGN approved the name Papanin Seamount, with coordinates of $46^{\circ} 15^{\prime} \mathrm{N}, 169^{\circ} 30^{\prime} \mathrm{E}$, based on Soviet sources. It is clear, however, that Papanin is the same feature as Jimmu, and the name Papanin lost USBGN approval in 1979.

\section{Kammu Seamount $\left(32^{\circ} 10^{\prime} \mathrm{N}, 173^{\circ} 00^{\prime} \mathrm{E}\right)$}

Kammu Seamount was named by Dietz (1954), but was there spelled Kanmu, which is the transliteration based on the Standard System of Romanization (or Kunreiski). Kanmu was approved by the USBGN in 1964, but corrected to Kammu in 1968. Kanmu appears frequently in the literature of the Emperor Seamounts, and on Chase (1970) Chart No. 7, but Kammu is used on $1906 \mathrm{~N}$ of the Atlas. Kammu was the 50th Emperor of Japan, and reigned from 782 to 805 . He was responsible for moving the capital to Kyoto. 


\section{Kimmei Seamount $\left(33^{\circ} 43^{\prime} \mathrm{N}, 171^{\circ} 30^{\prime} \mathrm{E}\right)$}

Kinmei (the Standard System spelling) was the name applied by Dietz (1954) to a seamount that appeared on Chart 6901 at $34^{\circ} 20^{\prime} \mathrm{N}, 171^{\circ} 45^{\prime} \mathrm{E}$. The name was approved by the USBGN in 1964, with nominal coordinates of $35^{\circ} 00^{\prime} \mathrm{N}, 171^{\circ} 45^{\prime} \mathrm{E}$. The original Chase (1970) bathymetry and $1906 \mathrm{~N}$ of the Atlas show what is now Kōkō Seamount as two large seamounts, the southernmost of which is situated at about the position of the 1964 USBGN coordinates for Kinmei. On $1906 \mathrm{~N}$ of the Atlas, the name Kinmei appears on the southern of the two seamounts, but on Chase (1970 and subsequent editions) Chart No. 7, the name appears between Kōkō and a seamount to the south of Kōkō centered at about $33^{\circ} 30^{\prime} \mathrm{N}, 171^{\circ} 30^{\prime} \mathrm{E}$. The survey of Davies et al. (1971, 1972) substantially revised the bathymetry in the vicinity of the Hawaiian-Emperor bend, making some adjustment in names desirable. Accordingly, the name Kimmei Seamount (Modified Hepburn System spelling) is now applied to the group of peaks between $33^{\circ} 30^{\prime} \mathrm{N}$ and $34^{\circ} 00^{\prime} \mathrm{N}$, and $171^{\circ}-172^{\circ} \mathrm{E}$, as has been customary in some recent publications (for example, Davies et al., 1971; Dalrymple and Clague, 1976). The revision of the coordinates and the spelling for Kimmei was approved by the USBGN in 1979. Kimmei reigned from 540 to 571 as the 29th Emperor.

\section{Kōkō Seamount $\left(35^{\circ} 15^{\prime} \mathrm{N}, 171^{\circ} 35^{\prime} \mathrm{E}\right)$}

The name was first used by Davies et al. (1972) and approved by the USBGN in 1979 . Kōkō was the 58 th Emperor of Japan, and ruled from 885 to 887 .

The name Beck Seamount was approved by the USBGN in 1975 for a feature at $35^{\circ} 35^{\prime} \mathrm{N}, 171^{\circ} 25^{\prime} \mathrm{E}$. The name was proposed by the Second Officer (Beck) of the S.S. Sealand Exchange, who provided some soundings, and was approved on the basis of the bathymetry shown on $1907 \mathrm{~N}$ of the Atlas. Since the Davies et al. $(1971,1972)$ bathymetry substantially revised $1907 \mathrm{~N}$ of the Atlas, and since Beck Seamount is the same as $K \bar{o} k \bar{o}$, the name Beck was dropped by the USBGN in 1979.

\section{Meiji Guyot $\left(53^{\circ} 05^{\prime} \mathrm{N}, 165^{\circ} 00^{\prime} \mathrm{E}\right)$}

The name Meiji was proposed by D. W. Scholl on behalf of the scientific staff of DSDP Leg 19 and approved by the USBGN in 1972. It was first used by Creager, Scholl, et al. (1973). Meiji was the reigning title of the 122nd Emperor Mutsuhito, who ruled from 1867 to 1912 .

\section{Milwaukee Seamounts $\left(32^{\circ} 28^{\prime} \mathrm{N}, 171^{\circ} 55^{\prime} \mathrm{E}\right)$}

The "Milwaukee Bank," with coordinates of $32^{\circ}$ $28^{\prime} \mathrm{N}, 171^{\circ} 55^{\prime} \mathrm{E}$, was discovered by the U.S.S. Milwaukee, a U.S. Navy light cruiser (CL-5), in May, 1929, and the name was in use at least as early as 1939 (Anonymous, 1940). Milwaukee Seamount Group was approved in 1963 by the USBGN for the features between $31^{\circ} 45^{\prime} \mathrm{N}$ and $32^{\circ} 45^{\prime}$ N. In 1971 , the USBGN replaced Seamount Group with Seamounts in all approved names. In current usage, the Milwaukee Seamounts include Yūryaku, Daikakuji, and Kammu.

\section{Minnetonka Seamount $\left(48^{\circ} 05^{\prime} \mathrm{N}, 168^{\circ} 30^{\prime} \mathrm{E}\right)$}

This seamount was named for the USCGC Minnetonka, a U.S. Coast Guard Cutter of the Lake class, which served in the North Pacific during the 1940's as part of the Ocean Station Patrol. The first use of the name is uncertain, but it was approved by the USBGN on the basis of the 1952 edition of $\mathrm{H}$. O. Chart BC2009N.

\section{Nintoku Seamount $\left(41^{\circ} 00^{\prime} \mathrm{N}, 170^{\circ} 40^{\prime} \mathrm{E}\right)$}

Nintoku was one of the nine seamounts named by Dietz (1954). The name was approved by the USBGN in 1964. Nintoku was the 16 th Emperor, and reigned from 313 to 399 . He was the son of Emperor Ōjin.

\section{Obruchev Rise $\left(52^{\circ} 30^{\prime} \mathrm{N}, 166^{\circ} 00^{\prime} \mathrm{E}\right)$}

This feature includes both Detroit Tablemount and Meiji Guyot. It was named for V. A. Obruchev; the name was used as early as 1955 by Bezrukov and Udincev (1955). The name received USBGN approval in 1966, on the basis of the Carte Tectonique Internationale du Monde (Congres Géologique International) and Soviet sources. The 1974 Atlas Okeanov-Tikhiy Okean restricts the name to west of $166^{\circ} \mathrm{E}$, i.e., to Meiji Guyot. In 1979 the USBGN, however, retained the name as first approved, i.e., for the broad swell that includes both Meiji Guyot and Detroit Tablemount.

\section{$\overline{\mathbf{O}}$ jin Seamount $\left(38^{\circ} 00^{\prime} \mathrm{N}, 171^{\circ} 30^{\prime} \mathrm{E}\right)$}

Ojin was named by Dietz (1954), and the name was approved by the USBGN in 1964. Ōjin reigned from 270 to 310 as the 15 th Emperor.

\section{Suiko Seamount $\left(44^{\circ} 30^{\prime} \mathrm{N}, 170^{\circ} 20^{\prime} \mathrm{E}\right)$}

Suiko Seamount was named by Dietz (1954), and the name was approved by the USBGN in 1967. Empress Suiko was Japan's 33rd sovereign, and reigned from 593 to 628 . She was the consort of the 30 th Emperor, Betatsu.

\section{Tenji Seamount $\left(49^{\circ} 00^{\prime} \mathrm{N}, 168^{\circ} 25^{\prime} \mathrm{E}\right)$}

Dietz (1954) used the name Tenchi, and the name was approved by the USBGN in 1964. The derivation of Dietz' spelling of the name is unknown. The spelling was corrected to Tenji in 1979. Subsequent bathymetry has shown that Tenji has a more complex form than that shown on Chart 6901. Under current usage, the name applies to the whole feature from about $48^{\circ} 30^{\prime} \mathrm{N}$ to $49^{\circ} 15^{\prime} \mathrm{N}$, and from $168^{\circ} 00^{\prime} \mathrm{E}$ to $169^{\circ} 20^{\prime} \mathrm{E}$. Tenji, who reigned from 668 to 671 , was the 38 th Emperor to rule Japan.

\section{Winnebago Seamount $\left(48^{\circ} 21^{\prime} \mathrm{N}, 168^{\circ} 04^{\prime} \mathrm{E}\right)$}

This seamount was named for the USCGS Winnebago, a U.S. Coast Guard Cutter of the Lake class, which served in the North Pacific during the 1940's as part of the Ocean Station Patrol. The first use of the name is unknown, but it was approved by the USBGN in 1964 , on the basis of the 1952 edition of $\mathrm{H}$. O. Chart $\mathrm{BC} 2009 \mathrm{~N}$, which showed the feature at $48^{\circ} 17^{\prime} \mathrm{N}$, $167^{\circ} 10^{\prime} \mathrm{E}$. The name was moved to fit the revised 
bathymetry shown on $2009 \mathrm{~N}$ of the Atlas, and the new coordinates were adopted by the USBGN in 1979 .

\section{Yōmei Seamount $\left(42^{\circ} 18^{\prime} \mathrm{N}, 11^{\circ} 24^{\prime} \mathrm{E}\right)$}

The name was proposed by the scientific staff of DSDP Leg 55 and approved by the USBGN in 1979. Yōmei was the 31st Emperor of Japan, and reigned from 586 to 587 . He was the fourth son of Emperor Kimmei.

\section{Yūryaku Seamount $\left(32^{\circ} 40^{\prime} \mathrm{N}, 172^{\circ} 15^{\prime} \mathrm{E}\right)$}

Yūryaku Seamount was named by Dietz (1954), and the name was approved by the USBGN in 1964. Yüryaku reigned from 457 to 479 as the 21 st Emperor.

\section{REFERENCES}

Anonymous, 1940. A brief summary of the oceanographic activities of the United States Navy in the Pacific Ocean since 1933, Sixth Pacific Sci. Congr., Pacific Sci. Assoc., Proc., v. III, p. 104-105.

Bargar, K. E., Marshall, M., and Trumbull, J. V. A., 1975. Bathymetry and ice-rafted pebbles from the northern end of the Emperor Seamount chain, U. S. Geol. Survey Openfile Rept. 75-609.

Bezrukov, P. L. and Udincev, G. B., 1955. The northern end of the Hawaiian Suboceanic Ridge, Dok. Akad. Nauk., v. 103, 6, p. 1077-1080.

Chase, T. E., Menard, H. W., and Mammerickx, J., 1970. Bathymetry of the North Pacific: Sheets 1-10, Scripps Institute of Marine Resources Technical Report Series TR-6.

Clague, D. A., 1974. The Hawaiian-Emperor Seamount chain: Its origin, petrology, and implications for plate tectonics, Ph.D. thesis, University of California, San Diego.
Creager, J. S., Scholl, D. W., et al., 1973. Initial Reports of the Deep Sea Drilling Project, v. 19: Washington (U.S. Government Printing Office).

Dalrymple, G. B. and Clague, D. A., 1976. Age of the Hawaiian-Emperor Bend, EPSL, v. 31, p. 313-329.

Davies, T. A., Clague, D. A., and Wilde, P., 1971. Preliminary report on Leg VII of Aries Expedition: Geological investigations in the Western north Pacific, July-August 1971, SIO Reference Series No. 71-21.

Davies, T. A., Wilde, P., and Clague, D. A., 1972. Kōkō Seamount: A major guyot at the southern end of the Emperor seamounts, Mar. Geol., v. 13, p. 311-321.

Dietz, R. S., 1954. Marine geology of northwestern Pacific: Description of Japanese bathymetric chart 6901, Geol. Soc. Am. Bull., v. 65, p. 1199-1224.

Green, H. G., Dalrymple, G. B., and Clague, D. A., 1978. Evidence for northward movement of the Emperor seamounts, Geology, v. 6, p. 70-74.

Larson, R. L., Moberly, R., et al., 1975. Initial Reports of the Deep Sea Drilling Project, v. 32: Washington (U.S. Government Printing Office).

Segawa, J., 1970. Gravity measurements at sea by use of the T.S.S.G. Part 2. results of the measurements, J. Phys. Earth, v. 18, p. 203-284.

Tayama, R., 1952. On the near-Japan bathymetric chart (introduction to the submarine geography of the northwest Pacific), Hydrographic Magazine, no. 32, p. 160-167 and 201 (in Japanese).

Tomoda, Y., 1968. Preliminary Report of the Hakuho Maru Cruise KH-68-3: Tokyo (Ocean Research Institute, University of Tokyo).

1974. Reference Book for Gravity, Magnetic and Bathymetric Data of the Pacific Ocean and Adjacent Seas, 1963-71: Tokyo (University of Tokyo Press). 